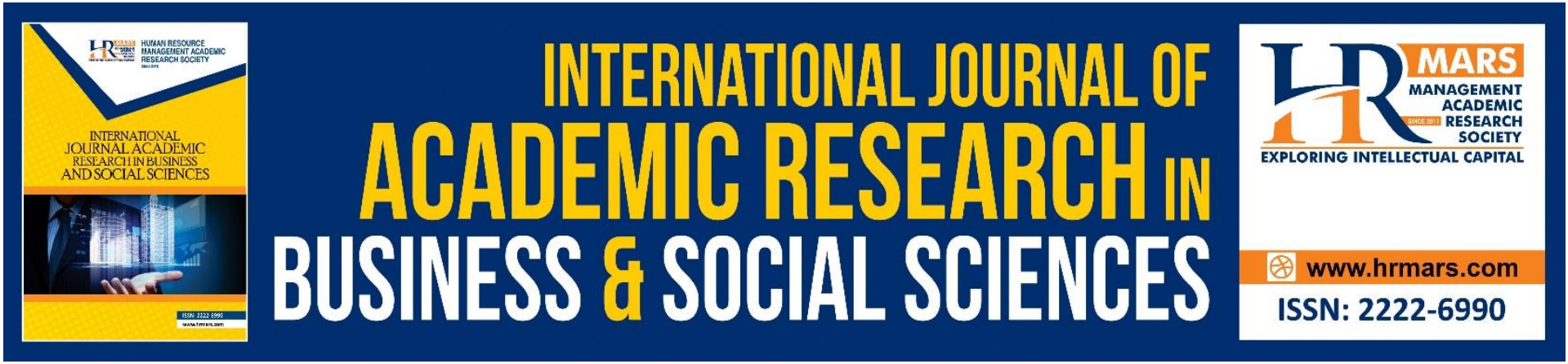

\title{
Concepts in Waste Management: A Preliminary Study
}

\section{Yuzlina Mohd Yusop, Nooraini Othman}

To Link this Article: http://dx.doi.org/10.6007/IJARBSS/v11-i2/8865

DOI:10.6007/IJARBSS/v11-i2/8865

Received: 11 January 2021, Revised: 01 February 2021, Accepted: 12 February 2021

Published Online: 28 February 2021

In-Text Citation: (Yusop \& Othman, 2021)

To Cite this Article: Yusop, Y. M., \& Othman, N. (2021). Concepts in Waste Management: A Preliminary Study. International Journal of Academic Research in Business and Social Sciences, 11(2), 546-557.

Copyright: (c) 2021 The Author(s)

Published by Human Resource Management Academic Research Society (www.hrmars.com)

This article is published under the Creative Commons Attribution (CC BY 4.0) license. Anyone may reproduce, distribute, translate and create derivative works of this article (for both commercial and non-commercial purposes), subject to full attribution to the original publication and authors. The full terms of this license may be seen

at: http://creativecommons.org/licences/by/4.0/legalcode

Vol. 11, No. 2, 2021, Pg. 546 - 557

Full Terms \& Conditions of access and use can be found at http://hrmars.com/index.php/pages/detail/publication-ethics 


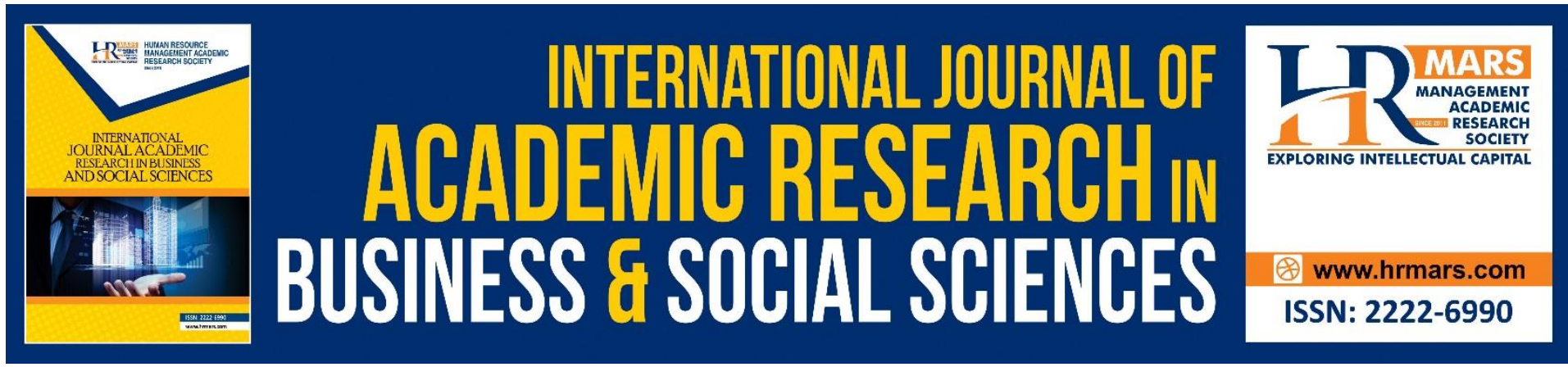

\title{
Concepts in Waste Management: A Preliminary Study
}

\author{
Yuzlina Mohd Yusop \\ Perdana Centre of Science, Technology \& Innovation Policy, Razak Faculty of Technology and \\ Informatics, UTM \\ Email: yyusop2000@yahoo.co.uk
}

\begin{abstract}
Nooraini Othman
Perdana Centre of Science, Technology \& Innovation Policy, Razak Faculty of Technology and Informatics, UTM

Email: p-noraini@utm.my
\end{abstract}

\begin{abstract}
This paper aims to discuss and highlight the basic concepts in waste management studies. Effective MSW management consists of a mix of policy instruments to achieve the policy objectives. Understanding the factors that have effects on public pro-environmental attitudes and behavior is important for helping decision makers to strengthen the existing policy frameworks for the future. Ensuring successful implementation of recycling and waste separation at source requires high participation from the household. Thus, this paper will discuss the relevant concepts in waste management studies that are relevant to assess the waste separation behavior from the socio-psychological model perspective. Understanding the factors that influence public waste separation behavior is useful to strengthen the existing policy framework.
\end{abstract}

Keywords: Solid Waste Management, Recycling Behaviour, Waste Separation Behavior, Theory of Planned Behavior, Perceived Policy Effectiveness

\section{Introduction}

Global waste generation is constantly increasing. The World Bank estimated that the urban population generates 2.2 billion tonnes of solid waste per year by 2025 (The World Bank, 2012). The rate of world urbanisation is occurring rapidly particularly within the lowincome nations (The World Bank, 2012; Vergara \& Tchobanoglous, 2012). Urbanization together with industrialization have led to continuous increase in demand for goods. Resources were taken from the nature for the production process which consequently consumed before finally being discarded. This results to short-age cycle of natural resources. Parallel to economic growth is the improved standards of living resulting to increased consumption inducing rapid generation of waste from both the industry and households. The global waste generation is projected to increase until its global peak in 2100 unless aggressive measures are implemented. In order to minimise the adverse impact to the 
environment, using waste as a resource has been adopted as part of waste management strategies.

The issue on waste generation has long been recognized that it received clear policy support from world leaders during the 'Earth Summit' in Rio de Janeiro in 1992. During the summit, Chapter 21 of Agenda 21 was launched setting the blueprint for a sustainable future among which include waste (Barr \& Gilg, 2005). Waste management cuts across various aspects of the economy and society as it impacted the health, environment as well as the economic development. SWM is "the discipline associated with controlling the generation, storage, collection, transfer and transport, processing, and disposal of solid waste in a manner that is in accordance with the best principles of health, economics, engineering, conservation, aesthetics, and other environmental considerations, and that is also responsive to public attitudes." (Asian Productivity Organization, 2007). Sustainable SWM which was introduced during the World Summit on Sustainable Development 2002 is the concept of managing waste based on its hierarchy starting from prevention, reduce, reuse, recycle and using environmentally sound technology for disposal.

\section{Solid Waste Scenario in Malaysia}

In a smaller scale, the ASEAN member state have an estimated total population of 625 million people, accounting for $8.8 \%$ of the total world population. It is projected that the population will increase to 650 million, with more than $50 \%$ living in urban areas. ASEAN waste generation is estimated at $1.14 \mathrm{~kg} / \mathrm{capita} /$ day with organic waste accounting for more than 50\% (UNEP, 2017). Other types of waste mainly plastic, paper and metals are common in MSW sites. Efforts are continuously being implemented to transform 'waste' into a 'resource'. Table 1 shows the annual MSW generation in ASEAN countries, with Malaysia ranking third after Singapore and Brunei Darussalam.

Table 1 : Waste generation by ASEAN countries

\begin{tabular}{|l|l|l|}
\hline Countries & $\begin{array}{l}\text { Annual MSW } \\
\text { Generation (In ton) }\end{array}$ & $\begin{array}{l}\text { Per Capita MSW } \\
\text { Generation (kg/capita/ } \\
\text { day) }\end{array}$ \\
\hline Brunei Darussalam & 210,480 & 1.4 \\
\hline Cambodia & $1,089,429$ & 0.55 \\
\hline Indonesia & $64,000,000$ & 0.70 \\
\hline Lao PDR & 77,380 & 0.69 \\
\hline Malaysia & $1,2840,000$ & 1.17 \\
\hline Myanmar & 841,508 & 0.53 \\
\hline Philippines & $14,660,000$ & 0.69 \\
\hline Singapore & $7,514,500$ & 3.763 \\
\hline Thailand & $26,770,000$ & 1.05 \\
\hline Viet Nam & $22,020,000$ & 0.84 \\
\hline
\end{tabular}

Source : UNEP Summary Report: Waste Management in ASEAN Countries, 2017.

Similarly, the increasing trend of waste generation has triggered a challenge in solid waste management in Malaysia. The growth in population, economic progress, rural-urban migration, and affluence has resulted to continuous demand of goods which eventually results to increasing volume of solid waste generation in Malaysia. The municipal solid waste (MSW) comprise a major percentage of solid waste generation, estimated at $64 \%$. Foods, 
papers and plastics were the major components of MSW which comprises $80 \%$ of the overall weight. The characteristics of MSW reflect the growing urbanisation lifestyle of Malaysian due to the significant increase in paper and plastic (Dinie, Samsudin, \& Don, 2013).

Household waste is the major composition in the MSW. The MSW generation increased from 21,455 tonnes per day (2000) to 33,000 tonnes per day (2012) (Johari, Alkali, Hashim, Ahmed, \& Mat, 2014; Moh \& Abd. Manaf, 2017). The average per capita urban resident generation of solid waste in Malaysia is estimated at about $0.80 \mathrm{~kg} /$ person/day which increases to $1.17 \mathrm{~kg}$ per person per day in 2016 (Mentek, 2017). Solid waste management becomes one of the major environmental issue in Malaysia because landfilling is the main disposal method. Currently, there are 157 disposal sites in operation but only 24 of these disposal sites are sanitary. $40 \%$ of the currently operating landfills are reaching is capacity in less than 5 years (Yahaya \& Larsen, 2008).

Solid waste management is one of the key utility services provided by local authority as improper waste management would result to adverse impact to the environment and human health. As stipulated in the Local Government Act 1976 in Section 72, the local authority is responsible to provide public cleansing services to all urban and semi-urban communities within its jurisdiction. The National Solid Waste Management Policy 2006 (NSWMP 2006) and the enactment of Solid Waste and Public Cleansing Management Act 2007 (Act 672) and The Solid Waste and Public Cleansing Management Corporation Act 2007 (Act 673) changes the landscape of SWM in Malaysia. Two entities were established which are National Solid Waste Management Department (Jabatan Pengurusan Sisa Pepejal Negara - JPSPN) and the Solid Waste Management and Public Cleansing Corporation (SWCorp). JPSPN is given the task to formulate policies, plans, and strategies while SWCorp undertakes the role as the operational arm.

The world has shifted its waste management towards sustainable waste management. Recycling has been globally accepted as one of the important methods of diverting the increasing amounts of municipal solid waste (MSW) from being deposited to the landfills, prolonging the lifespan of the landfills, turns the waste into a resources which reduces the use of virgin material in production. Malaysia has promoted recycling through its first recycling programme in 1993, but received low response from the public. The relaunched of the recycling programme in 2000 received the same fate due to lack of participation from the market players, local authorities, policies and action plans (Moh \& Manaf, 2014). Various scholars has reported the poor participation of household in performing recycling (Karim Ghani, Rusli, Biak, \& Idris, 2013; Moh \& Abd. Manaf, 2017; Murad \& Siwar, 2007). Under the Act 672, Malaysia launched the waste separation at source on 15 September 2015 while enforcing it effective 1 June 2016.

\section{Theories and Basic Concepts in Waste Management Research}

Recycling refers to the process of converting used materials which are collected, processed and transformed into valued resources. Recycling rates in developed countries have gradually increased driven by the EU revised Waste Framework Directive (European Commission, 2008), which targets to turn Europe into a recycling society requiring the EU member state to recycle $65 \%$ of municipal waste by 2030 . Recycling behavior is unique as it requires individual effort to sort, prepare and store materials before disposing. The success of recycling and waste separation programmes are highly dependent on household or individual participation. The difficulty to explain the reason for individual participation in such behavior is the reason for this line of research being one of the most studied 
environmentally responsible behavior (Boldero, 1995). Recycling may have different antecedents from other types of pro-environmental behavior such as water conservation and electricity conservation. Furthermore, recycling different types of waste such as newspaper, food and plastic may be determined by different antecedents.

Recycling and waste separation behaviour research can broadly be classified into four. The first stream of research aims to profile recyclers from non-recyclers (Oskamp et al., 1991; Boldero, 1995; De Young, 1986; Do Valle et al., 2004). Variables such as knowledge of environmental conservation, beliefs, attitudinal variables and demographic variables were used to understand recycler profile. Second stream of research investigates the effectiveness of intervention strategies through experimental techniques (Timlett and Williams, 2008; Schill and Shaw, 2016). Intervention strategies includes psychological factors and contextual factors such as knowledge, social influence, convenience modification, collection services, incentives, information and behavior modelling. Written information is perhaps the most common intervention method used to promote recycling. The third stream of research is socio-cultural research that studied the society-environment interaction such as the role of the informal sector and the impact on their vulnerability in the waste management system. The final stream of research is the socio-psychological models which helps to understand the socio-psychological influences on recycling behavior. The socio-psychological stream has enrich the literature based on frameworks from Theory of Reasoned Action, Theory of Planned behavior, Value-Belief-Norm and Norm Activation Model of altruistic behavior (Davies, Foxall, \& Pallister, 2002; do Valle, Rebelo, Reis, \& Menezes, 2005; Sebastian \& Moser, 2007).

The Norm Activation Model was developed by Schwartz proposing that behavior can be explained based on the interrelationships of four main constructs which are personal norms, social norms, awareness of consequences and ascription of responsibility. The model suggest that the influence of social norm on behavior is mediated by personal norm of altruistic behavior. While the correlation between personal norm and behavior is moderated by two variables which are awareness on consequences and the ascription of responsibility(do Valle et al., 2005). The theory holds that pro-environmental action will occur as a response to personal moral norms about performing the action which is activated by individual beliefs on the threats pose to the environment and that the action could avert the consequences. Social norm represent the values held by specific referents such as family members or social groups; personal norm is conceptualized as feeling of moral obligation. The NAM model will be effective to measure desired behavior only if there are positive belief on consequences of the behavior and personally feeling responsible to perform the behavior. As emphasized by Davies et al. (2002), norm internalization process is important to understand kerbside recycling behavior in Cotswold District Council, United Kingdom.

Value-Belief-Norm is the revised version of NAM that links NAM with the value theory and the New Environmental Paradigm (Stern, 2000). The theory contains five variables in a causal chain of personal values, New Environmental Paragidm, awareness of consequences, ascription of responsibility and personal norms for pro-environmental. The theory holds that the values of a person would activate one's belief of ecological worldview which results to belief in adverse environmental consequences and belief to ascribe into responsibility to reduce the threat. These induced-beliefs will result to the personal norm of obligation to perform the pro-environmental actions (Stern, 2000). The VBN theory strongly suggest that personal norm is the basis for engagement into pro-environmental behaviour. 
Most often within the literature of recycling framework, the Theory of Reasoned Action (TRA) and the Theory of Planned Behavior (TPB) have dominated the attempts to predict social behavior to explain what drives recycling (Davies et al., 2002). The TRA has mostly been applied in research on environmental cognition and has been used widely in social behavior. Most often within the literature on recycling the (TPB) is used to explain or predict what drives recycling (Ramayah et al., 2012)(Lizin, Dael, \& Passel, 2017). The theory of reasoned action proposed that attitude and subjective norms are the two determinants towards intention to perform a certain behaviour. The TPB has its foundation from the TRA which is expanded to include Perceived Behaviour Control (PBC) to represent the beliefs in terms of difficulty and controllability to perform the behavior (Ajzen, 1985). The TPB has been preferred by scholars due to its flexible application to suit various research areas. The TPB has been used in various pro-environmental behavior research such as energy conservation (Fan et al., 2019), pro-environment travel behavior (Chen et al., 2019), urban green space (Wan et al., 2015) and green purchasing (Onel et al., 2015).

In Malaysia, most studies centered on the general picture of the status of solid waste management (Shahul Hamid \& Periathamby, 2012; Zainu, Syukri, Mohamad, \& Songip, 2015). Several studies on profiling the socio-demographic for undertaking recycling behavior includes W. Murad and Siwar (2007), R. Afroz and M. Masud (2011), I. Zen et al. (2014) and A. Akil et al. (2015). There are a few studies within the context of the socio- psychological model studies to explain recycling and waste separation. Whilst TPB has extensively been used in research investigating household recycling in the western countries, research in Asian context is rather limited (Goh, Yoon, \& Ahmed, 2018; Wan, Qiping, \& Choi, 2017). With waste recycling remain an important agenda, it is essential to understand factors influencing household recycling behavior in Malaysia. Table 2 provides the summary of the variables used and the result of previous studies.

Table 2: Review on TRA/TPB-based studies investigating recycling behavior in Malaysia

\begin{tabular}{|l|l|l|l|l|l|}
\hline Author & Recycling & $\begin{array}{l}\text { Theor } \\
\text { y }\end{array}$ & Variable 1 & $\begin{array}{l}\text { Variable } \\
\mathbf{2}\end{array}$ & $\begin{array}{l}\text { Variable } \\
\mathbf{3}\end{array}$ \\
\hline $\begin{array}{l}\text { N Jekriya \& S. Daud } \\
\text { (2016) }\end{array}$ & $\begin{array}{l}\text { Waste } \\
\text { Recycling }\end{array}$ & TRA & $\begin{array}{l}\text { Environmenta } \\
\text { I Concern (+) }\end{array}$ & $\begin{array}{l}\text { Attitude } \\
(+)\end{array}$ & $\begin{array}{l}\text { Behaviou } \\
\text { r }\end{array}$ \\
\hline $\begin{array}{l}\text { S. Latif et al. (2012) } \\
\text { Waste } \\
\text { Recycling }\end{array}$ & TRA & $\begin{array}{l}\text { Environmenta } \\
\text { I Values (+) }\end{array}$ & $\begin{array}{l}\text { Intention } \\
\text { (NS) }\end{array}$ & $\begin{array}{l}\text { Behaviou } \\
\text { r }\end{array}$ \\
\hline $\begin{array}{l}\text { Ramayah et al. } \\
\text { (2012) }\end{array}$ & $\begin{array}{l}\text { Waste } \\
\text { Recycling }\end{array}$ & TPB & ATT (+) & SN (+) & PBC (NS) \\
\hline $\begin{array}{l}\text { Goh et al. (2018) } \\
\text { Waste } \\
\text { Recycling }\end{array}$ & TPB & ATT (+) & SN (+) & PBC (+) \\
\hline $\begin{array}{l}\text { W. Karim Ghani et } \\
\text { al. (2017) }\end{array}$ & $\begin{array}{l}\text { Food Waste } \\
\text { Separation }\end{array}$ & TPB & ATT (+) & SN (+) & PBC (+) \\
\hline $\begin{array}{l}\text { S. Mahmud \& K. } \\
\text { Osman }\end{array}$ & $\begin{array}{l}\text { Waste } \\
\text { Recycling }\end{array}$ & TPB & ATT (-) & SN(+) & PBC(+) \\
\hline
\end{tabular}

ATT = Attitude, $\mathrm{SN}=$ Subjective Norm, $\mathrm{PBC}=$ Perceived Behaviour Control, NS=Not significant, $(+)=$ positive relationship, $(-)=$ negative relationship. 
Ensuring successful implementation of recycling and waste separation at source requires high participation from the household. Thus, this paper will discuss on the other relevant concepts in waste management studies that may increase the predictive power of the model. As mentioned earlier, as of June 2016, through the National Solid Waste Management Policy 2016 and the enforcement of the Solid Waste Management and Public Cleansing Act 2007, recycling has been made mandatory among the household. Various types of public policies has been implemented at reducing solid waste and increase participation in recycling. Information creates awareness, regulation increases compliance level while economic incentives provides the inducement to perform the desired behaviour. In addition, information can also act be used as meta-policy instrument to spread the information about other policy instruments. The effectiveness evaluation of these policy instruments is necessary to provide feedback mechanism in the policy cycle. It is an essential tool to improve understanding for policy makers to further enhance policy implementation.

Policy instruments are government tools of utilising its financial, human capacity and institutions to achieve policy goals. Government interventions through policy instruments vary from legislation to voluntary programs. The approaches such as mandatory waste separation schemes, waste charging schemes, curbside collection, landfill ban and community waste separation bins are a few to be named (Xevgenos, Papadaskalopoulou, Panaretou, Moustakas, \& Malamis, 2015). Regulatory instruments, commonly used to prescribe or prohibit behaviour. Market instruments such as tax and subsidies and regulatory instruments of changing the norms has been the common tool but inclination is towards market instrument (Kirakozian, 2016). The public perception on the effectiveness of policy measures will influence their behaviour. The inclusion of the variables on perceived policy effectiveness increases the attitude and behavior relationships (Steg and Vlek, 2009). Perceived policy effectiveness is an important variable to provide the feedback loop to improve policy implementation at the local level.

The study by C. Wan et al. (2014) defines Perceived Policy Effectiveness (PPE) as the respondents' perception on how effective has the government policies been implemented on the ground. The achievement of the policy goals depends on the implementation policy tools choice adopted that have to be adapted to the local and social conditions. The behavioral dimension of policy tools is vital at formulating better strategies and plans to comprehend the response of the target population to the policy initiative. There are several taxonomy of policy tools which this study adopts McDonell and Elmore (1986) policy categorization.

\section{Perceived Policy Effectiveness}

PPE capacity building refers to the investment made on materials and human resources to meet the long term developmental objectives. Information is a meta-policy instrument used in the policy tool to spread the information on the implemented programmes and strategies. As highlighted in the SWCorp Strategic Plan 2014-2020, among their core strategies include the 'Communicate, Educate, Engage, Empower, and Enforce' (C4E) to increase public awareness (Moh \& Abd. Manaf, 2017). Scholars including Vining and Ebreo (1990) and Oke and Kruijsen (2016) has indicated that providing information is a key factor to affect public awareness. In addition, information relating to explain the benefit and outcome of recycling has proved to result in positive engagement to recycling. Another part of capacity building is convenience for performing waste separation and recycling such as bin availability and the distance to send waste for collection (Chen and Tung, 2010; Sidique et al, 2010). 
PPE mandates refers to the authority tools that legitimises the government authority to preventing or requiring certain actions to be performed under specified circumstances (Schneider \& Ingram, 1990). In the current waste management policy, household are required to separate their household waste at source accordingly failing which household will be subjected to penalties. Current Act also vested the SWCorp with the authority to issue warnings and compounds to households who does not separate their waste at source.

PPE inducement refers to the offerings of economic or non-economic incentives to act as the push factor to perform the desired behavior. Individuals are utility maximisers whom will likely to perform the desired behavior in the availability of incentives. In the study by $\mathrm{C}$. Liao (2018), inducement is referred to waste charge, monetary bonus as well as public praise. Within the context of recycling centers and buy back centers provides the economic incentives for residents. Therefore the availability and convenience of the recycling centres will provide the positive responses to the public to sort their waste at home.

PPE System Changing refers to the new arrangement of delivering public goods and services (Elmore, 1987). Public hearing, meetings and outreach programmes are the common methods for public participation (Suzie et al., 2015). Study by Folz and Hazlett (1991) found that institution with professional expertise and familiarity with community leaders yielded greater achievement in getting the public to recycle. In addition, the process of aggregating public opinion creates the transparency in decision making process that in turn provides more support towards the policy. In the modern society, multi-way interaction between the public, the government and other players are crucial to influence action in achieving the policy goals.

\section{Conclusion}

The increasing trend of waste generation has triggered a challenge in solid waste management in Malaysia. The critical challenge for promoting waste reduction through waste separation and recycling is household participation. The National Solid Waste Management Policy 2006 (NSWMP 2006) and Solid Waste and Public Cleansing Management Act 2007 (Act 672) and Solid Waste and Public Cleansing Management Corporation Act 2007 (Act 673) has changed the setting of SWM in Malaysia. Scholars have highlighted four research streams on waste sorting behavior assessing various angles of psychological and contextual factors. The research on socio-psychological models helps to understand the socio-psychological factors based on theoretical framework, mostly dominated by Theory of Planned Behaviour, to understand factors influencing waste sorting (Chen and Tung, 2010; Lizin, 2017). Policies are vital to effectively promote MSW management behavior change. However, the effectiveness of these policies has many implementation issues that may lead to non-action. Therefore, perceived policy effectiveness is an important perspective to assess these limitation. Understanding the factors that have effects on public proenvironmental attitudes and behaviour are important for assisting decision makers to strengthen the existing policy framework by understanding the other motivational factors. Recycling is an essential long-term solution to the waste problem that getting full participation, particularly the household, is critical to its success.

\section{References}

Abdul Latif, S., Omar, M. S., Bidin, Y. H., \& Awang, Z. (2012). Environmental Problems and Quality of Life: Situational Factor as a Predictor of Recycling Behaviour. Procedia-Social and Behavioral Sciences, 35(December 2011), 682-688. 
https://doi.org/10.1016/j.sbspro.2012.02.137

Afroz, R., \& Masud, M. M. (2011). Using a contingent valuation approach for improved solid waste management facility: Evidence from Kuala Lumpur, Malaysia. Waste Management, 31(4), 800-808. https://doi.org/10.1016/j.wasman.2010.10.028

Ajzen, I. (1991). The theory of planned behavior. Organizational Behavior and Human Process, 50, 179-211. https://doi.org/https://doi.org/10.1016/0749-5978(91)90020-T

Akil, A. M., Foziah, J., \& Ho, C. S. (2015). The Effects of Socio-Economic Influences on Households Recycling Behaviour In Iskandar Malaysia. Procedia - Social and Behavioral Sciences, 202(December 2014), 124-134. https://doi.org/10.1016/j.sbspro.2015.08.215

Barr, S., \& Gilg, A. W. (2005). Conceptualising and Analysing Household Attitudes and Actions to a Growing Environmental Problem Development and Application of a Framework to Guide Local Waste Policy. Applied Geography, 25, 226-247. https://doi.org/10.1016/j.apgeog.2005.03.007

Boldero, J. (1995). The prediction of household recycling of newspapers : The role of attitudes, intentions, and situational factors. Journal of Applied Social Psycology, 25(5), 440-462.

Chen, F., Chen, H., Huang, X., Long, R., Lu, H., \& Yue, T. (2017). Public Response to the Regulation Policy of Urban Household Waste: Evidence from a Survey of Jiangsu Province in China. https://doi.org/10.3390/su9061034

Chen, M. F. (2016). Extending the theory of planned behavior model to explain people's energy savings and carbon reduction behavioral intentions to mitigate climate change in Taiwan-moral obligation matters. Journal of Cleaner Production, 112, 1746-1753. https://doi.org/10.1016/j.jclepro.2015.07.043

Chen, M., \& Tung, P. (2010). The moderating effect of perceived lack of facilities on consumers' recycling intentions. Environment and Behavior, 42(6), $824-844$. https://doi.org/10.1177/0013916509352833

Davies, J., Foxall, G. R., \& Pallister, J. (2002). Beyond The Intention-Behaviour Mythology. An integrated model of recycling. Marketing Theory, 2(1), 29-113.

do Valle, P. O., Rebelo, E., Reis, E., \& Menezes, J. (2005). Combining Behavioural Theories to Predict Recycling Involvement. Environment and Behavior, 37(3), 364-396. https://doi.org/10.1177/0013916504272563

Dinie, M., Samsudin, M., \& Don, M. M. (2013). Municipal Solid Waste Management in Malaysia : Current Practices, Challenges and Prospect. Jurnal Teknologi, 1, 95-101.

Elmore, R. F. (1987). Instruments and strategy in public policy. Policies Studies Review, 7(1), 174-186.

Fan, Y., Xu, J., \& Nie, H. (2019). Exploring reasons behind careful-use, energy-saving behaviors in residential sector based on the theory of planned behavior : Evidence from Changchun , China, 230. https://doi.org/10.1016/j.jclepro.2019.05.101

Folz, D. H. (1999). Recycling Policy and Performance Trends in Participation, Diversion, and Costs. Public Works Management \& Policy, 4(2), 131-142.

Goh, M., D. Yoon, E. Ahmed. (2018). Exploring households' recycling behaviour in a world heritage city, Melaka. Jurnal Pengurusan, 54, 27-38, https://ejournal.ukm.my/pengurusan/article/view/30071/9353

Jekria, N., \& Daud, S. (2016). Environmental Concern and Recycling Behaviour. Procedia Economics and Finance, 35(October 2015), 667-673. https://doi.org/10.1016/S22125671(16)00082-4 
Johari, A., Alkali, H., Hashim, H., Ahmed, S. I., \& Mat, R. (2014). Municipal Solid Waste Management and Potential Revenue from Recycling in Malaysia. Modern Applied Science, 8(4). https://doi.org/10.5539/mas.v8n4p37

Ghani, K. W. A. W. A., Rusli, I. F., Biak, D. R. A., \& Idris, A. (2013). An Application of the Theory of Planned Behaviour to Study the Influencing Factors of Participation in Source Separation of Food Waste. Waste Management, 33(5), 1276-1281. https://doi.org/10.1016/j.wasman.2012.09.019

Kirakozian, A. (2016). The determinants of household recycling: social influence, public policies and environmental preferences. Applied Economics, 6846(July). https://doi.org/10.1080/00036846.2015.1102843

Liao, C., Zhao, D., Zhang, S., \& Chen, L. (2018). Determinants and the moderating effect of perceived policy effectiveness on residents' separation intention for rural household solid waste. International Journal of Environmental Research and Public Health, 15(4), 117. https://doi.org/10.3390/ijerph15040726

Liu, J., Snow, J., \& Che, T. (2019). Understanding perceived environment quality in affecting tourists' environmentally responsible behaviors : A broken windows theory perspective. Tourism Management Perspectives, 31(41471467), 236-244.

https://doi.org/10.1016/j.tmp.2019.05.007

Lizin, S., Dael, M. V., \& Passel, S. V. (2017). Battery pack recycling: Behavior change interventions derived from an integrative theory of planned behavior study. Resources, Conservation \& Recycling, 122, 66-82. https://doi.org/10.1016/j.resconrec.2017.02.003

Ma, J., \& Hipel, K. W. (2016). Exploring social dimensions of municipal solid waste management around the globe - A systematic literature review. Waste Management, 56, 3-12. https://doi.org/10.1016/j.wasman.2016.06.041

Mahmud, S. N. D., \& Osman, K. (2010). The Determinants of Recycling Intention Behavior Among the Malaysian School Students : an Application of Theory of Planned Behaviour, 9, 119-124. https://doi.org/10.1016/j.sbspro.2010.12.123

Mentek, M. (2017). Solid Waste Management in Malaysia : Towards A Holistic Approach. In ISWA World Congress. Ministry of Urban Wellbeing,Housing and Local Government. Retrieved from http://www.swcorp.gov.my/docfile/kertas-taklimat/Towards a Holistic Approach.pdf

Moh, Y. C., \& Manaf, L. A. (2017). Solid waste management transformation and future challenges of source separation and recycling practice in Malaysia. "Resources, Conservation \& Recycling," 116, 1-14. https://doi.org/10.1016/j.resconrec.2016.09.012

Moh, Y. C., \& Manaf, L. A. (2014). Overview of household solid waste recycling policy status and challenges in Malaysia. Resources, Conservation \& Recycling, 82, 50-61. https://doi.org/10.1016/j.resconrec.2013.11.004

Murad, W., \& Siwar, C. (2007). Waste management and recycling practices of the urban poor: a case study in Kuala Lumpur city ,. Waste Management \& Research, 1(25), 3-13. https://doi.org/10.1177/0734242X07070766

Nurudin, M. S., Hashim, R., Rahman, S., Zulkifli, N., Mohamed, A. S. P., \& Hamik, S. A. (2015). Public participation process at local government administration: A case study of the Seremban Municipal Council, Malaysia. Procedia - Social and Behavioral Sciences, 211, 505-512. https://doi.org/10.1016/j.sbspro.2015.11.067

Oke, A., \& Kruijsen, J. (2016). The Importance of Specific Recycling Information in Designing a Waste Management Scheme. Recycling, 1, 271-285.

https://doi.org/10.3390/recycling1020271 
Onel, N., \& Mukherjee, A. (2015). Understanding environmentally sensitive consumer behaviour: an integrative research perspective. World Journal of Entrepreneurship, Management and Sustainable Development, 11(1), 2-16. https://doi.org/10.1108/WJEMSD-07-2014-0021

Ramayah, T., Lee, J. W. C., \& Lim, S. (2012). Sustaining the environment through recycling: An empirical study. Journal of Environmental Management, 102, 141-147. https://doi.org/http://dx.doi.org/10.1016/j.jenvman.2012.02.025

Safitri Zen, I., Zainon Noor, Z., \& Yusuf, R. O. (2014). The profiles of household solid waste recyclers and non-recyclers in Kuala Lumpur, Malaysia. Habitat International, 42, 83-89. https://doi.org/10.1016/j.habitatint.2013.10.010

Schill, M., \& Shaw, D. (2016). Recycling today, sustainability tomorrow: Effects of psychological distance on behavioural practice. European Management Journal. https://doi.org/10.1016/j.emj.2016.05.004

Schneider, A., \& Ingram, H. (1990). Behavioral assumptions of policy tools. The Journal of Politics, 52(2), 510-529.

Schwartz, S. H. (2012). An Overview of the Schwartz Theory of Basic Values. Online Readings in Psychology and Culture, 2(1). https://doi.org/10.9707/2307-0919.1116

Sebastian, B., \& Moser, G. (2007). Twenty years after Hines, Hungerford , and Tomera : A new meta-analysis of psycho-social determinants of pro-environmental behaviour. Journal of Environmental Psychology, 27, 14-25. https://doi.org/10.1016/j.jenvp.2006.12.002

Hamid, S. F., \& Periathamby, A. (2012). Trends in Sustainable Landfilling in Malaysia, a Developing Country. Waste Management \& Research, 30(7), 656-663. https://doi.org/10.1177/0734242X12437564

Sidique, S. F., Lupi, F., \& Joshi, S. V. (2010). The effects of behavior and attitudes on drop-off recycling activities, 54, 163-170. https://doi.org/10.1016/j.resconrec.2009.07.012

Steg, L., \& Vlek, C. (2009). Encouraging pro-environmental behavior : An integrative review and research agenda. Journal of Environmental Psychology, 29(3), 309-317. https://doi.org/10.1016/j.jenvp.2008.10.004

Taylor, S., \& Todd, P. (1995). An integrated model of waste management behavior: A test of household recycling and composting intentions. Environment and Behavior, 27(5), 603630.

The World Bank. (2012). What a Waste: A Global Review of Solid Waste Management. Retrieved from https://openknowledge.worldbank.org/handle/10986/17388

Timlett, R. E., \& Williams, I. D. (2008). Public Participation and Recycling Performance in England: A comparison of Tools for Behaviour Change. Resources, Conservation and Recycling, 52, 622-634. https://doi.org/10.1016/j.resconrec.2007.08.003

Valle, O. D. P., Reis, E., Menezes, J., \& Rebelo, E. (2004). Behavioral determinants of household recycling participation: The Portuguese case. Environment and Behavior, 36(4), 505-540. https://doi.org/10.1177/0013916503260892

Varotto, A., \& Spagnolli, A. (2017). Psychological srategies to promote household recycling. A systematic review with meta-analysis of validated field interventions. Journal of Environmental Psychology, 51, 168-188. https://doi.org/10.1016/j.jenvp.2017.03.011

Vergara, S. E., \& Tchobanoglous, G. (2012). Municipal Solid Waste and the Environment : A Global Perspective. Annual Review of Environment Resources, 37, 277-303. https://doi.org/10.1146/annurev-environ-050511-122532 
Wan, C., Qiping, G., \& Choi, S. (2017). Experiential and instrumental attitudes : Interaction effect of attitude and subjective norm on recycling intention. Journal of Environmental Psychology, 50, 69-79. https://doi.org/10.1016/j.jenvp.2017.02.006

Wan, C., Shen, G. Q., \& Yu, A. (2014a). The moderating effect of perceived policy effectiveness on recycling intention. Journal of Environmental Psychology, 37, 55-60. https://doi.org/10.1016/j.jenvp.2013.11.006

Wan, C., Shen, G. Q., \& Yu, A. (2014b). The role of perceived effectiveness of policy measures in predicting recycling behavior in Hong Kong. "Resources, Conservation \& Recycling," 83, 141-151. https://doi.org/10.1016/j.resconrec.2013.12.009

Wang, Z., Zhang, B., Yin, J., \& Zhang, Y. (2011). Determinants and policy implications for household electricity-saving behavior: Evidence from Beijing, China. Energy Policy, 39(6), 3550-3557. https://doi.org/10.1016/j.enpol.2011.03.055

Xevgenos, D., Papadaskalopoulou, C., Panaretou, V., Moustakas, K., \& Malamis, D. (2015). Success Stories for Recycling of MSW at Municipal Level : A Review. Waste and Biomass Valorization, 6(5), 657-684. https://doi.org/10.1007/s12649-015-9389-9

$\mathrm{Xu}$, L., Ling, M., Lu, Y., \& Shen, M. (2017). Understanding household waste separation behavior: Testing the roles of moral, past experience and perceived policy effectiveness within the theory of planned behavior. Sustainability, 9(4), 625. https://doi.org/10.3390/su9040625

Yahaya, N., \& Larsen, I. (2008). Federalising Solid Waste Management In Peninsular Malaysia. In Proceeding of International Solid Waste Association (ISWA) World Congress, Singapore.

Zainu, Z. A., Syukri, W., Mohamad, W., \& Songip, A. R. (2015). Present and Future Innovations in Solid Waste Management in Malaysia, 21-27.

Zen, I. S., Zainon N. Z., \& Yusuf, R. O. (2014). The profiles of household solid waste recyclers and non-recyclers in Kuala Lumpur, Malaysia. Habitat International, 42, 83-89. https://doi.org/10.1016/j.habitatint.2013.10.010

Zhang, D., Huang, G., Yin, X., \& Gong, Q. (2015). Residents' waste separation behaviors at the source : Using SEM with the theory of planned behavior in Guangzhou, China. Int. J. Environ. Res. Public Health, 9475-9491. https://doi.org/10.3390/ijerph120809475

\section{Others}

Directive 2008/98/EC on waste (Waste Framework Directive). Retrieved from https://ec.europa.eu/environment/waste/framework/

SWCorp Malaysia. (2014). Pelan Strategik SWCorp 2014-2020: Melakar Dimensi Baharu Menuju Masa Depan. Retrieved from http://www.swcorp.gov.my

UNEP. (2017) Summary Report: Waste Management in ASEAN Countries. Retrieved from https://environment.asean.org/wp-content/uploads/2020/03/Summary-Report-WasteManagement-in-ASEAN-Countries-UNEP.pdf assessed on 18/1/2021. 